the instrument, the chancellor was of the view that, viewed musically, it would be hard to conclude that the petitioners had rebutted the presumption in favour of pipe organs. No specific shortcomings had been identified with the instrument, which had a 'most pleasant tone' and was of some local interest. The petition was nevertheless granted because the petitioners had made out a case for re-ordering the north chapel so that it could be used more flexibly, for meetings, social gatherings and discussion groups. The presence of the organ in the chapel was an obstacle to such use of the chapel and the instrument would have to be removed in order to facilitate the re-ordering. As there was nowhere in the church to relocate it, it would have to be disposed of and replaced by the proposed electronic organ, which would be installed where three pews currently stood. [Alexander McGregor]

doi:10.1017/So956618X12000191

\title{
JGE v English Province of Our Lady of Charity and another
}

High Court, Queens Bench Division: MacDuff J, November 2011 Sexual abuse - vicarious liability

The claimant alleged that while resident between 1970 and 1972 in a children's home managed by the Sisters of Our Lady of Charity she was raped by the now deceased Father Baldwin. In these interlocutory proceedings the issue was whether or not the second defendants, the Trustees of the Portsmouth Roman Catholic Diocese, were vicariously liable for Baldwin's wrongful acts. The Trustees denied liability on the grounds that Baldwin was not their employee. Following the reasoning in Maga $v$ Trustees of the Birmingham Archdiocese of the Roman Catholic Church [2010] EWCA Civ 256, the court concluded that, by 'appointing Father Baldwin as a priest' [sic] and thus clothing him with all the powers involved, the defendants created a risk of harm to others. At the time of writing an appeal was pending. [Frank Cranmer]

doi:10.1017/So956618X12000208

\section{Re Coultous, deceased}

Bradford Consistory Court: Walford Ch, November 2011 Exhumation

The chancellor granted a faculty for the exhumation of the cremated remains of the deceased, which had been buried as long ago as 1977. Since the burial 
the church, hall and vicarage adjoining the burial ground had been demolished and the character of the area in which it stood had changed dramatically. The family had felt an increasing sense of alienation and anguish in relation to these changes. They were intending to bury the remains of the deceased's wife elsewhere and wished to bury the remains of the deceased in the same place. The chancellor found that circumstances existed that justified making an exception to the norm of permanence in Christian burial. [RA]

doi:10.1017/So956618X1200021X

\section{St Michael and All Angels, Bexhill}

Chichester Consistory Court: Hill Ch, November 2011

Lead theft - interim faculties - dispensation from faculty

The chancellor gave a judgment in consolidated proceedings relating to four petitions and one application for a dispensation from faculty. Each matter concerned the replacement of stolen lead on listed church buildings and the chancellor sought to provide guidance for future cases throughout the diocese. In each case the chancellor had already permitted the works to proceed on the basis of urgency but had directed that full consultation should take place with the amenity societies, English Heritage (EH), the local planning authorities, the Church Buildings Council (CBC), the churches' insurers and the diocesan advisory committee. The chancellor summarized the evidence and advice tendered by the various bodies and then set down guidance for the future conduct of similar cases. He acknowledged that the theft of roof coverings can create an emergency situation, as the integrity of the building is often compromised. Given the urgency that often arises, the chancellor noted that a dispensation from faculty or an interim faculty might be appropriate. $\mathrm{He}$ listed circumstances in which a dispensation from faculty may be suitable, namely:

i. Where the church is unlisted or, exceptionally, where the affected part of a listed church is of no particular significance;

ii. Where the church has been subject to repeated thefts or is at significant risk of future theft;

iii. Where the affected area is not visible from the ground and/or forms no part of the historic or aesthetic importance of the church;

iv. Where the cost of the work (excluding scaffolding) does not exceed $£ 7,500$. 